\title{
СЕМАНТИКА И ФУНКЦИОНИРОВАНИЕ ГЛАГОЛА ВЗМАЛИВАТЬСЯ/ВЗМОЛИТЬСЯ В ПРОЗЕ М. ГОРЬКОГО И ЕГО КИТАЙСКИЕ АНАЛОГИ
}

\section{SEMANTICS AND FUNCTIONING OF THE VERB IMPLORE IN PROSE M. GORKY AND ITS CHINESE ANALOGUES}

Fu Yamei

Summary: The paper deals with the semantics and functioning of verbs expressing speech influence in the prose of M. Gorky and their Chinese counterparts. The semantic, linguistic and cultural features of the verbal lexeme are considered within the framework of the historical and cultural process of the Chinese nation. The analysis algorithm presented in the paper can have theoretical and practical value in the courses on Russian as a foreign language.

Keywords: dictionary paper, semantics, verbs of speech influence, word combination, use of grammatical forms, emotional expression, Chinese counterparts.
И 3 анализа словарных статьей в различных словарях, посвященных семантике исследуемого в данной статье глагола взмаливаться/взмолиться, который входит в лексико-семантическую группу глаголов речевого воздействия [1], можно сделать вывод, что основным значением этого глагола следует считать просить (молить/умолять, упрашивать, молиться).

Попутно отметим, что авторы словарей указывают спряжение глагола (взмолюсь, взмолишься), вид и ударение глагола, а также и его управление (кому-чему или к кому-чему), что очень важно для изучающих русский язык иностранных учащихся.

В исследуемой прозе М. Горького можно обнаружить следующие примеры: Tenерь, когда Челкаш говорил спокойно и даже добродушно, Гаврила, все еще дрожащий от страха, взмолился: - Слушай, отпусти ты меня! Христом прошу, отпусти! Высади куда-нибудь! («Челкаш» 1894) [7]. В этом примере глагол взмолился соответствует его словарному значению. Далее мы видим, что Гаврила взмолился + все еще дрожащий от страха перед Челкашом, это, как указано в словаре, «значит, он боится этого человека или события» [3]. Можно представить, что когда Гаврила взмолился, у него дрожал голос, то есть голос прерывался и звучал неровно. В переводе на китайский язык глагол взмолился переведен как 他哀求道 (он взмолился и сказал). Обратим внимание на то, что прошед-

\author{
Фу Ямэй \\ Аспирант, Санкт-Петербургский \\ государственный университет \\ fu.yam@yandex.ru
}

Аннотация: В статье речь идёт об особенностях семантики и функционирования глаголов речевого воздействия в прозе М. Горького и их китайских аналогах. Семантические и лингвокультурологические особенности глагольной лексемы рассматриваются в рамках историко-культурного процесса китайской нации. Представленный в статье алгоритм анализа может иметь теоретическую и практическую ценность на занятиях по русскому языку как иностранному.

Ключевые слова: словарная статья, семантика, глаголы речевого воздействия, словосочетание, употребление грамматических форм, эмоциональное выражение, китайские аналоги.

шее время данного глагола в переводе не обнаружено. Следующее несовпадение в русском и китайском текстах относится к тому, что переводчик добавил личное местоимение 他 (он) перед 哀求 (взмолился). В китайском языке глагол не имеет спряжения в прошедшем времени и согласования по родам, поэтому надо указать, он или она в данном примере являются действующим лицом, что восполняет этот пробел. Переводчик добавил иероглиф 道 (сказать) после 哀求 (взмолился), это говорит о том, что иероглиф道в данном случае является глаголом, в котором совмещается семантика глагола с дополнением, присутствующим в русском языке. Это совмещение способствует, если после этого иероглифа стоит точка, тому, что содержание речи уже проявилось, а если после этого иероглифа стоит двоеточие, то содержание речи проявится, как это и представлено в рассказе М. Горького «Челкаш».

Рассмотрим другой пример: Но раньше, чем лошадь достигла его, он перенёсся в баню, где с каменки удушливо растекался жгучий пар хлебного кваса, а рядом с ним на мокром полу сидел весь в язвах человек с лицом Дроздова, дёргал себя за усы и говорил жутким голосом: - Взмолился я, взмолился я, взмолился... Вдруг окно лопнуло, распахнулось, и, как дым, повалили в баню плотные сизые облака, приподняли, закружив, понесли и бросили в колючие кусты. («Жизнь Матвея Кожемякина»1910). 
В данном примере глагол взмолился отражает словарное значение: «начать упрашивать» [2]. Но автор, употребив сочетание жутким голосом, что значит, голос «приводящий в ужас, вызывающий чувство беспокойного страха, тягостный, неприятный» [6], подчеркнул высокую степень своей просьбы, которая была вызвана страшным сном.

Перевод взмолился я, взмолился я, взмолился можно считать соответствующим общему замыслу автора. Если обратить внимание на китайские иероглифы в переводе 我哀求, 我哀求, 哀求 (я взмолился, я взмолился, взмолился), то можно увидеть, что грамматическое значение данного глагола (прошедшее время, единственное число, мужской род) в китайском языке не отражено, как и тот порядок слов, который использовал М. Горький в повести «Жизнь Матвея Кожемякина».

Приведем ещё пример: И взмолились они тогда ко госnодy: «Госnоди! Госnодu!..» Фома знает эту страшную сказку о крестнике бога, не раз он слышал ее и уже заранее рисует пред собой этого крестника: вот он едет на белом коне к своим крестным отиу и матери, едет во тьме, по пустыне, и видит в ней все нестерпимые муки, коим осуждены грешники...(«Фома Гордеев» 1899). В данном примере глагол взмолились переведен как 哀 求了(взмолиться + вспомогательное слово) и отражает его словарное значение. Но, порядок слов в китайском языке отличается от русского языка, то есть в китайском языке получается тогда они к Богу взмолились. Переводчик добавил вспомогательный иероглиф 了, который в китайском языке после глагола или прилагательного используется для того, чтобы указать на изменение действия.

Проанализируем следующий пример: С другим бы тем и кончилось, но артельщик был парень не дурак, взмолился он к ним: Братиы. Я человек служащий, деньги это не мои, а заводские, хозяйские, жалованье рабочим, не поверят мне, что меня ограбили, скажут сам я украл деньги. («Несвоевременные мысли» 1917-1918). В этом примере глагол взмолился тоже соответствует его словарному значению, но в китайском языке порядок слов другой, местоимение с предлогом к ним (向他们) в русском языке поставлено после глагола (взмолился) и местоимения (он), но в китайском языке это сочетание обязательно должно стоять перед глаголом (взмолился) и после подлежащего (он). Конструкция в китайском языке выглядит следующим образом: подлежащее, предлог к, затем какое-либо существительное либо местоимение, а глагол стоит в самом конце, то есть в китайском языке получается 他向他们哀求道 (он к ним взмолился).

В русско-китайских словарях данный глагол обозначает 《哀求起来，恳求起来》 (начать скорбно просить, на- чать убедительно просить), 《苦苦哀求起来，央告起来》 (начать просить с горестью, начать упрашивать).

Китайский переводчик 叶水夫 (Е Шуйфу) перевел повесть «Челкаш», переводчик 李兰 (Ли Лань) работала над прозой «Фома Гордеев», ещё некоторые переводчики, не оставившие своих имён, тоже работали над переводами прозы М. Горького. В их переводах глагол взмаливаться/взмолиться всеми переведен как 哀求, в словарях современного китайского языка глагол 哀求обозначает 《央告 ; 哀告请求 ; 苦苦请求》 [9] (упрашивать, жалобно умолять и просить, просить с горечью). Считается, что в китайском языке глагол 哀求 (взмолиться) впервые появился в книге «Тайпин Гуанджи», которая была напечатана в 978 году нашей эры: «太平广记»卷七十二 : “老人以 杖画地，遂成一水，阔丈余。生吅头哀求，老人日：吾 去日语汝，勿入权贵家。故违我命，患自捜也；然亦不 可不救尔。"[8] (Когда старик начал рисовать палкой на земле, образовалась река шириной более одного чжан. Лу Шэн, поклонившись до земли старику, взмолился, и старик сказал: «Я же сказал тебе в день твоего ухода, не входи в могущественный дворянский дом. Ты сознательно не повиновался моим приказам и сам навлёк беду, но я не могу не спасти тебя»). В дополнение кратко объясним, что эта история направлена на то, чтобы научить китайцев прощать другим их ошибки. Можно вспомнить, что великий китайский философ 左丘明 (Цзо Цюмин), живший в одно время с Конфуцием, тоже говорил об этом, и каждый китаец хорошо знает эту заповедь: «人 谁无过，过而能改，善莫大焉。» [9] (Кто не виноват? Нет ничего лучше, чтобы исправить ошибку).

Анализ исследуемого в данной статье глагола показывает, что его семантика и в древнем китайском языке, и в современном китайском языке не изменилась, его употребление в рамках контекста часто сопровождается эмоциональными выражениями действующего лица или телодвижениями. Это, на наш взгляд, усиливает значение данного глагола, делает его содержание более полным и богатым.

В китайском языке 哀求 (взмолиться) подчеркивает печаль и жалость в мимике и взгляде говорящего при его просьбе. Глагол 哀求 (взмолиться) - это нейтральное слово, оно фокусирует читателя на способе просьбы: просить с большой горечью. Что касается выражения эмоций, то глагол взмолиться обладает оттенком жалости, он в основном используется в контексте для описания речи и поведения слабых героев. В нашем примере герой Гаврила дрожит от страха, поэтому он взмолился, а не просто обратился с просьбой. Такое представление автором мимики и телодвижения героя показывает его жалкость и слабость, то есть такое описание поведения героя, выражающее его эмоциональное состояние, в переводе совпадает с самим контекстом русской прозы. 
Анализируя словари, нетрудно обнаружить, что в русском языке значение сочетания «начать упрашивать или умолять» $[4,5]$ в китайском переводе, имея в виду глагол начать, не отражено, но отражено в русско-китайских словарях. Кроме того, в толковых китайских словарях глагол 哀求 (взмолиться) фокусирует наше внимание на просьбах, произносимых с жалостью, с горечью и даже мучительно, а в русских же словарях это не отражено.

Таким образом, анализ семантики и функционирования исследуемого в данной статье глагола позволяет сделать вывод, что в русском и китайском языках его семантика по смыслу в основном совпадает, но оттенки, подчеркивающие степень эмоционального состояния героев, белее выразительны в китайском языке. По употреблению же грамматических форм и конструкций, а также по порядку слов русские и китайские конструкции отличаются, иногда значительно. Это требует внимания при изучении русского языка китайскими учащимися, которые, не зная этого, могут не совсем верно уловить то, какой смысл вложил писатель, употребляя анализируемые нами глаголы в свои произведения.

\section{ЛИТЕРАТУРА}

1. Бабенко Л.Г. Толковый словарь русских глаголов: Идеографическое описание. Английские эквиваленты. Синонимы. Антонимы / Под ред. проф. Л.Г. Бабенко. - М.: АСТ-ПРЕСС, 1999. - 347-371 с.

2. Даль В.И. Толковый словарь живого великорусского языка. - М.: Терра, 2006. - 1432 с

3. Дмитриев Д.В. Толковый словарь русского языка. - М.: Астрель: АСТ, 2003. - 1578 с.

4. Кузнецов С.А. Большой толковый словарь русского языка. / Сост. и гл. ред. С.А. Кузнецов. - СПб.: «Норинт», 1998. - 1536 с.

5. Ожегов С.И., Шведова Н.Ю. Толковый словарь русского языка: 80000 слов и фразеологических выражений/Российская академия наук. Институт русского языка им. В.В. Виноградова. - 4-е изд., дополненное. - М.: Азбуковник, 1999. - 944 с.

6. Ушаков Д.Н. Толковый словарь русского языка. Том ІІІ. Под ред. Д.Н. Ушакова. - М.: 000 Изд-во Астрель, 000 Изд-во АСТ, 2000 . - 720 с.

7. Национальный корпус русского языка. - URL: http://ruscorpora.ru/new/search-main.html (дата обращения: 25.06.2020)

8. 台湾教育部国语推行委员会.教育部重编国语辞典修订本[DB/0L]. http://dict.revised.moe.edu.tw/cbdic/.(Комитет по развитию китайского языка Министерства образования Тайваня. Новая версия словаря китайского языка под редакцией Министерства образования).

9. 中国社会科学院语言研究所词典编辑室编 现代汉语词典 第七版.一北京:商务印书馆，2016,-1800页.(Редакционная комната словаря, институт языковых исследований Китайской академии социальных наук, Современный словарь китайского языка. Том VII. - Пекин: Коммерческая пресса, 2016. - 1800 с.).

○) Фу Ямэй (fu.yam@yandex.ru).

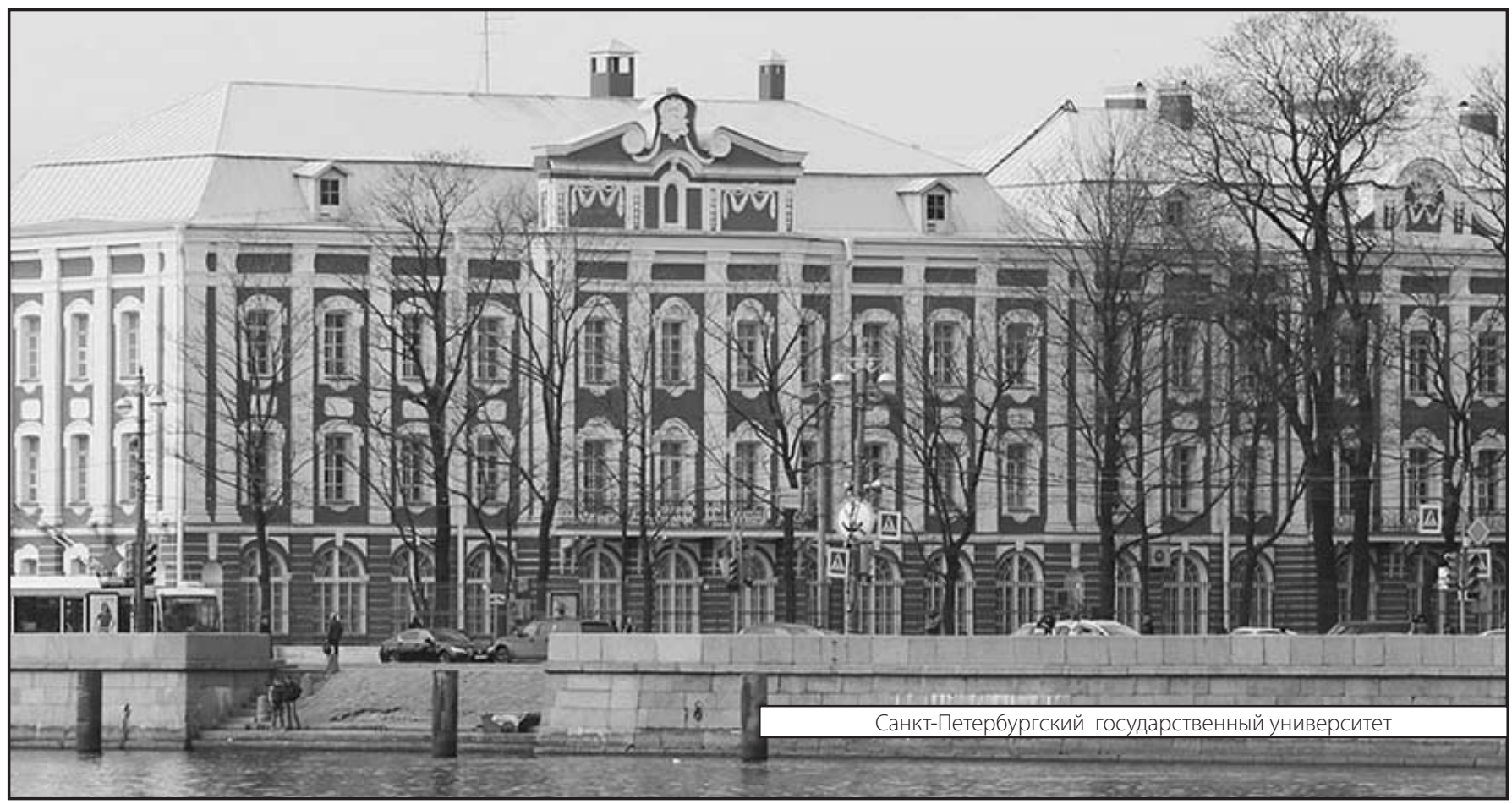

